\title{
Article \\ Carbonation of High-Ca Fly Ashes under Flue Gas Conditions: Implications for Their Valorization in the Construction Industry
}

\author{
Kwon Rausis ${ }^{1, *}$, Agnieszka Ćwik ${ }^{1,2, *}$, Ignasi Casanova ${ }^{1,3}$ and Katarzyna Zarębska ${ }^{2}$ \\ 1 Institute of Energy Technologies, Barcelona Research Center in Multiscale Science and Engineering, Campus \\ Diagonal Besòs, Universitat Politècnica de Catalunya, Building C. Av. Eduard Maristany, 16, \\ 08019 Barcelona, Spain; ignasi.casanova@upc.edu \\ 2 Faculty of Energy and Fuels, AGH University of Science and Technology, Al. Mickiewicza 30, \\ 30-059 Cracow, Poland; katarzyna.zarebska@agh.edu.pl \\ 3 Department of Civil and Environmental Engineering, Campus Nord, Universitat Politècnica de Catalunya, \\ B1-106C, 08034 Barcelona, Spain \\ * Correspondence: kwonrausis@trentu.ca (K.R.); cwikagnieszka1@gmail.com (A.Ć.)
}

Citation: Rausis, K.; Ćwik, A.; Casanova, I.; Zarębska, K. Carbonation of High-Ca Fly Ashes under Flue Gas Conditions: Implications for Their Valorization in the Construction Industry. Crystals 2021, 11, 1314. https://doi.org/ $10.3390 /$ cryst11111314

Academic Editor: Chongchong Qi

Received: 1 October 2021

Accepted: 23 October 2021

Published: 28 October 202

Publisher's Note: MDPI stays neutral with regard to jurisdictional claims in published maps and institutional affiliations.

Copyright: (c) 2021 by the authors. Licensee MDPI, Basel, Switzerland. This article is an open access article distributed under the terms and conditions of the Creative Commons Attribution (CC BY) license (https:// creativecommons.org/licenses/by/ $4.0 /)$

\begin{abstract}
The utilization of high-calcium fly ashes (HCFA) from coal-fired power plants in the construction industry is problematic, since their high free lime contents can lead to durability problems. In this research, the carbonation of a high-CaO fly ash has been carried out using simulated flue gas and concentrated $\mathrm{CO}_{2}$, with the aim to assess the valorization potential of such materials in the construction industry. The results show that, at 7 bars total pressure, an up to $36 \%$ carbonation efficiency can be achieved in just $30 \mathrm{~min}$ when pure $\mathrm{CO}_{2}$ is used; a comparable result with flue gas requires about $4 \mathrm{~h}$ of reaction. On the other hand, experiments carried out at atmospheric pressure show significantly different carbonation efficiencies depending on the $\mathrm{CO}_{2}$ concentration of the gas used. All experiments resulted in a substantial reduction in the original free lime content, and after reaction times of $4 \mathrm{~h}$ (at atmospheric pressure) and pressures of 7 bars (for any reaction time $>30 \mathrm{~min}$ ), the final free lime values were low enough to comply with the requirements of European Standards for their utilization as additions in cement.
\end{abstract}

Keywords: carbon dioxide; industrial waste; gas-solid carbonation; coal fly ash

\section{Introduction}

The utilization of Coal Combustion Products (CCPs) in Europe is a subject of the requirements for different standards imposed by the national authorities. One of the main products among the CCPs is fly ash-inorganic residue remaining after combustion. Based on its composition, fly ash is divided mainly into two groups: siliceous fly ash, containing 70 wt. \% of $\mathrm{SiO}_{2}+\mathrm{Al}_{2} \mathrm{O}_{3}+\mathrm{Fe}_{2} \mathrm{O}_{3}$, and high-calcium calcareous fly ash (HCFA), with $\mathrm{SiO}_{2}+\mathrm{Al}_{2} \mathrm{O}_{3}+\mathrm{Fe}_{2} \mathrm{O}_{3}$ between 50 and $70 \%$ [1]. HCFA is usually rich in calcium oxide $(10-50 \%)$ and due to this, the utilization possibilities of this waste are limited. With the worldwide production of $675 \mathrm{mln}$ tonnes, $80 \%$ of siliceous fly ash and only $20 \%$ of HCFA are utilized [2]. The general standardization of the use of fly ash in the construction industry is called '450-1:2012-Fly ash for concrete. Definition, specifications and conformity criteria' and the main requirements of it are shown in Table $1[3,4]$.

In Europe, with the significant use of lignite coal, the amount of produced HCFA is very high in countries such as: Germany, Greece, Poland, Serbia and Czech Republic [5]. Since the HCFA does not meet the standards imposed by the EU 450-1:2012, it only has a few applications [3,6-10]. As the use of coal for energy production is still increasing, more ash is produced every year and the disposal of this waste is becoming an environmental issue [11]). Regulations regarding the fly ash admixtures to cement are imposed due to the high content of lime present in the ash. As the major compound of cement is lime, using HCFA as an additive will additionally increase the lime content. During the concrete curing 
process, additional lime could add to the hardening behavior of the concrete mixture as the calcium compounds take part in cementitious and pozzolanic reactions [12]. Additionally, there are many factors influencing the final fly ash composition [13] and the possible variations in lime content make adding this type of fly ash to cement problematic [14]. According to Table 1, which presents the chosen requirements for fly ash application to cement's maximum value of free calcium oxide, the contents of fly ash should be less or equal to $1.5 \%$. If this value is higher, additional tests for soundness have to be performed.

Table 1. Chosen requirements for fly ash according to the EN 450-1:2013. LOI-lost on ignition.

\begin{tabular}{ccc}
\hline Property of Fly Ash & Unit & Requirement Accord. 450-1:2012 \\
\hline LOI & $\%$ by mass & $5-9$ (depending on class) \\
water requirement & $\%$ & $\leq 95$ \\
total phosphate $\left(\mathrm{P}_{2} \mathrm{O}_{5}\right)$ & $\mathrm{mg} / \mathrm{kg}$ & $\leq 5$ \\
sum $\mathrm{SiO}_{2}+\mathrm{Al}_{2} \mathrm{O}_{3}+\mathrm{Fe}_{2} \mathrm{O}_{3}$ & $\%$ by mass & $\geq 70$ \\
total content of alkalis & $\%$ & $\leq 5$ \\
reactive $\mathrm{CaO}$ & $\%$ & $\leq 10$ \\
sulphate $\left(\mathrm{SO}_{3}\right)$ & $\%$ & $\leq 3$ \\
free $\mathrm{CaO}$ & $\%$ & if $\geq 1.5 \%$, fly ash is checked for soundness \\
soundness & mm & $\leq 10$ \\
magnesium oxide $\mathrm{MgO}$ & $\%$ by mass & $\leq 0.10$ \\
chloride $\left(\mathrm{Cl}^{-}\right)$ & $\%$ by mass &
\end{tabular}

On the other hand, increased amounts of $\mathrm{CaO}$ in HCFA can be carbonated during the mineral carbonation process. In this reaction, carbon dioxide reacts with the alkali-bearing materials and is converted into a thermostable product-carbonate. In recent research, both natural minerals [15-17] and also industrial wastes [18-20] have been considered. It is a well-established fact that in order to improve the kinetics of the carbonation process, it has to be accelerated [21,22]. In the case of HCFA, mineral carbonation, in addition to utilizing $\mathrm{CO}_{2}$, might also lead to the decrease in free lime by its transformation to calcium carbonate. Eventually, carbonated fly ash could be used as admixture for the cement production [23,24]. The literature on this shows that there is much interest in HCFA carbonation $[22,25,26]$ and the use of carbonated fly ash in cement production $[24,27]$. It has been approximated that the addition of $5 \%$ of carbonated fly ash as cement admixture could save USD 1.96 on 1 ton of cement produced [24].

Following our previous results $[28,29]$, the studies have been extended to performing carbonation with simulated flue gas $\left(84 \% \mathrm{~N}_{2}, 15 \% \mathrm{CO}_{2}\right.$ and $\left.1 \% \mathrm{H}_{2} \mathrm{O}\right)[30,31]$ and comparing the results with the same experiments using concentrated $\mathrm{CO}_{2}$. Capturing $\mathrm{CO}_{2}$ as an initial step is avoided if flue gas is used instead of concentrated $\mathrm{CO}_{2}$ for mineral carbonation reactions [32-35]. The experiments were conducted under atmospheric and 7 bars pressure at $160{ }^{\circ} \mathrm{C}$ during reaction times of $0.5-4 \mathrm{~h}$. In addition to the general analysis of materials before and after the experiment, a free lime determination test was conducted in order to reveal the decrease in calcium oxide content. Therefore, this research has two objectives. Firstly, to determine the $\mathrm{CO}_{2}$ utilization in waste fly ash by using flue gas. Both reactants for this process are produced at a power plant site and a carbonation reactor could be easily added as a part of flue gas and ash treatment. Additionally, using flue gas for carbonation instead of a pure stream of $\mathrm{CO}_{2}$ would save the cost of the gas stream separation [36]. Our decond objective is to decrease the free lime in HCFA to the values compatible with EU 450-1:2012. The carbonation of lime has been extensively studied for the capture of carbon dioxide from many different gas streams including flue gases [37].

\section{Test materials and Methods}

\subsection{Test Materials}

Experiments were conducted on the fly ashes resulting from combustion of lignite coal from the Main and Northern lignite fields in the Ptolemaida power station, Ptolemais, Greece. It has 660 MWe installed electrical power and consists of 5 electric blocks equipped 
with electrostatic precipitators. The chemical composition of the fly ash is shown in Table 2. In a first approximation, if all of the calcium of the samples is considered to be accessible for carbonation, the theoretical maximum $\mathrm{CO}_{2}$ sequestration capacity amounts to $277.1 \mathrm{~g}$ $\mathrm{CO}_{2} / \mathrm{kg}$ fly ash. As discussed below, the initial $\mathrm{CO}_{2}$ content of the sample is $1.4 \%$. XRD analysis of received fly ash shows the presence of lime $(\mathrm{CaO})$, quartz $\left(\mathrm{SiO}_{2}\right)$, gehlenite $\left(\mathrm{Ca}_{2} \mathrm{Al}_{2} \mathrm{SiO}_{7}\right)$, anhydrite $\left(\mathrm{CaSO}_{4}\right)$ and calcite $\left(\mathrm{CaCO}_{3}\right)$.

Table 2. Chemical analysis of the tested fly ash.

\begin{tabular}{cc}
\hline Compound & \% Content \\
\hline $\mathrm{CaO}$ & 35.27 \\
\hline $\mathrm{SiO}_{2}$ & 33.11 \\
$\mathrm{Al}_{2} \mathrm{O}_{3}$ & 13.76 \\
$\mathrm{MgO}$ & 3.21 \\
$\mathrm{Na}_{2} \mathrm{O}$ & 1.33 \\
$\mathrm{SO}_{3}$ & 4.98 \\
$\mathrm{~K}_{2} \mathrm{O}$ & 0.95 \\
$\mathrm{Fe}_{2} \mathrm{O}_{3}$ & 5.72 \\
$\mathrm{TiO}_{2}$ & 0.67 \\
$\mathrm{P}_{2} \mathrm{O}_{5}$ & 0.35 \\
\hline
\end{tabular}

\subsection{Methods}

Experiments were conducted using the designed apparatus described in [32] at $160^{\circ} \mathrm{C}$, using either a pure stream of $\mathrm{CO}_{2}$ or a mix of $84 \% \mathrm{~N}_{2}, 15 \% \mathrm{CO}_{2}$ and $1 \% \mathrm{H}_{2} \mathrm{O}$ (heretofore referred to as simulated flue gas), at atmospheric and 7 bars pressure over 0.5, 1, 2 and $4 \mathrm{~h}$. Appropriate flow rates of $\mathrm{CO}_{2}$ and $\mathrm{N}_{2}$ were calculated and used throughout the experiment in order to achieve the chosen gas mixture. Addition of water vapor was carried out through an external bubbler connected to the gas pipeline.

X-ray fluorescence spectroscopy (XRF) analyses were performed on a UniQuant machine from Thermo Fisher Scientific ${ }^{\mathrm{TM}}$ using the fusion bead method. Prior to each experiment, the fly ash samples were heated for $2 \mathrm{~h}$ at $1000{ }^{\circ} \mathrm{C}$. The mineral composition of the material was determined by powder diffraction (XRD) method with a Bruker D8 ${ }^{\mathrm{TM}}$ advanced diffractometer, equipped with a theta-theta goniometer, in the $2 \theta$ range from $20^{\circ}$ to $60^{\circ}$ and with a step size of $0.02^{\circ}$ per second. Characterization of the starting and carbonated materials by Fourier-Transform Infrared Spectroscopy (FTIR) was carried out with a FTIR Nicolet $6700^{\mathrm{TM}}$ spectrometer. An attenuated total reflection (ATR) module was used to record spectra on a germanium crystal. Temperature programmed desorption of $\mathrm{CO}_{2}$ $\left(\mathrm{CO}_{2}\right.$-TPD) data were acquired with a BELCAT-MTM instrument, equipped with a thermal conductivity detector, at a heating rate of $10{ }^{\circ} \mathrm{C} / \mathrm{min}$ from room temperature to $850{ }^{\circ} \mathrm{C}$, under a He flow of $50 \mathrm{~mL} / \mathrm{min}$. Scanning electron microscopy (SEM) images of powder samples were obtained with a crossbeam workstation Zeiss Neon $40^{\mathrm{TM}}$, equipped with an INCAPentaFET energy dispersive $\mathrm{X}$-ray (EDx) system for elemental analysis, operated at $5 \mathrm{keV}$.

\section{Results and Discussion}

\subsection{Analysis of the Material before and after Experiment}

The results of the $\mathrm{X}$-ray diffraction of materials treated with simulated flue gas and pure $\mathrm{CO}_{2}$ are shown in Figure 1. Calcite's presence becomes evident after $0.5 \mathrm{~h}$ of reaction at atmospheric pressure using flue gas. Additionally, portlandite XRD peaks [38] were identified in samples carbonated for $0.5 \mathrm{~h}$ at atmospheric pressure using flue gas or concentrated $\mathrm{CO}_{2}$, as well as after $4 \mathrm{~h}$ in the reaction with flue gas. Upon carbonation, lime peaks positioned at $2 \theta$ of $37.5^{\circ}$ and $54^{\circ}$ [39] disappeared and calcite emerged, suggesting that lime is a precursor of calcite. Moreover, the hydration of lime to form portlandite was also observed, particularly in experiments carried out at atmospheric pressure. This process fixes easily accessible Ca within portlandite instead of calcite, which is undesirable. At 
higher pressures, the competing hydration and carbonation of lime is not observed as portlandite features are not identified, either indicating that the lime has directly carbonated into calcite or underwent hydration followed by the carbonation of this hydrated product.
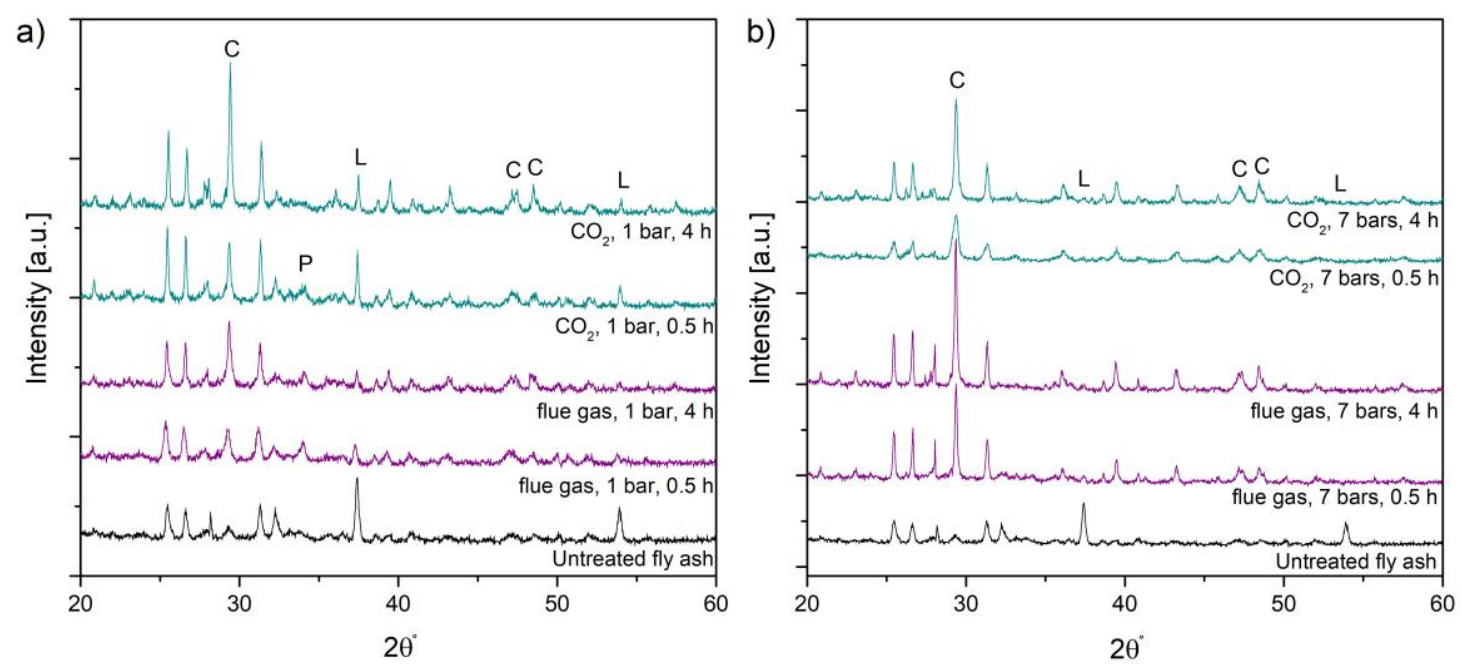

Figure 1. XRD analysis of fly ash carbonated using concentrated $\mathrm{CO}_{2}$ and flue gas over 0.5 and $4 \mathrm{~h}$ at (a) atmospheric and (b) 7 bars pressure. $\mathrm{C}$-calcite, $\mathrm{L}$-lime, $\mathrm{P}$-portlandite. ash occurs.

This observation is also supported by the FTIR results (Figure 2). One of the characteristic absorption bands from silicious components of this fly ash occurs at $\sim 1119 \mathrm{~cm}^{-1}$ (stretching vibration of $\mathrm{Si}-\mathrm{O}$ ); similar bands at the same position and intensity were identified in carbonated and untreated samples [40]. Furthermore, the characteristic absorption bands for calcite at $\sim 872 \mathrm{~cm}^{-1}$ and $\sim 1423 \mathrm{~cm}^{-1}$ [41] were observed to increase in intensity from the starting materials to the reaction products, indicating the progressive formation of carbonates as the reaction proceeds. Untreated fly ashes have pre-existing carbonates, which probably originated when fresh fly ash reacted with atmospheric $\mathrm{CO}_{2}$ during storage, before sampling these materials for the experiments. Such carbonates were hardly detected by XRD analysis, which is probably due to their poor abundance and/or the presence of amorphous Ca-carbonates.

The morphologies of the starting and carbonated materials were studied by SEM (Figure 3). The most abundant components of the HCFA are round to semi-spherical cenospheres, composed mainly of aluminosilicate glass and quartz [42,43]. The observed platy features are portlandite crystals, based on the morphology features [44] and the mineralogy observed with XRD (Figure $3 b$ ). Upon reaction with $\mathrm{CO}_{2}$ during the flue gas experiments, aggregates of rhombohedric crystals were identified and attributed to newly formed carbonates (Figure 3c,d) $[38,45,46]$. In agreement with previous observations, rhombohedric calcite appears to cover the entire surface of the cenospheres upon carbonation (Figure 3d). This is particularly evident when comparing cenospheres in as-received (Figure 3a) and treated fly ashes (Figure 3c,d). 


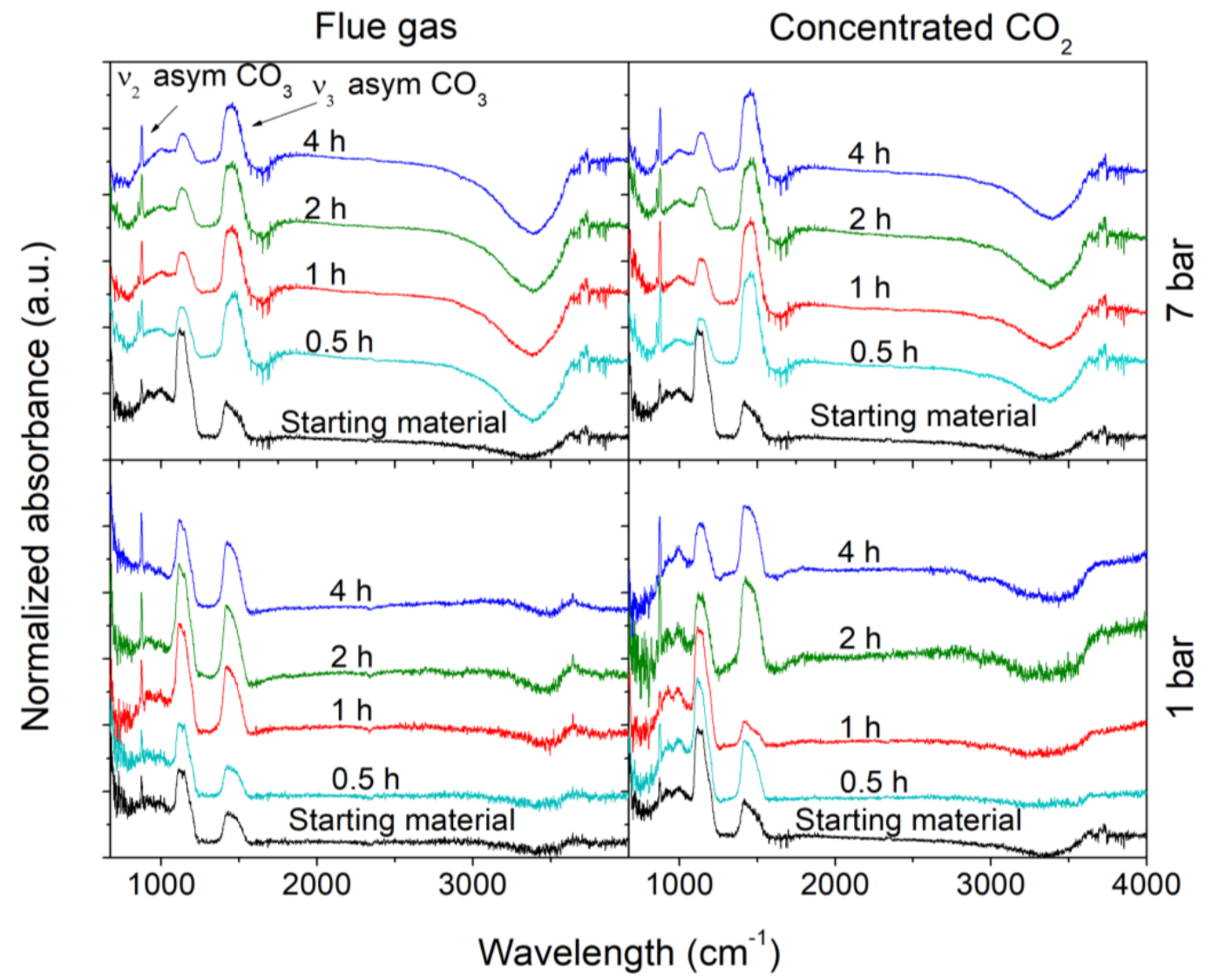

Figure 2. FTIR-ATR analysis of untreated and carbonated fly ash samples.

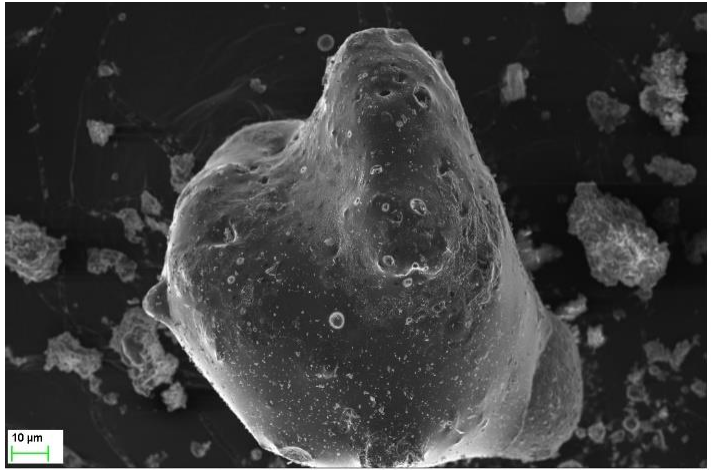

(a)

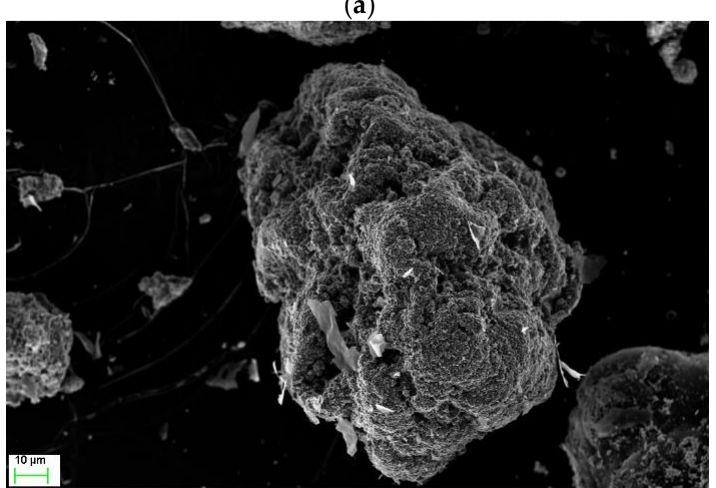

(c)

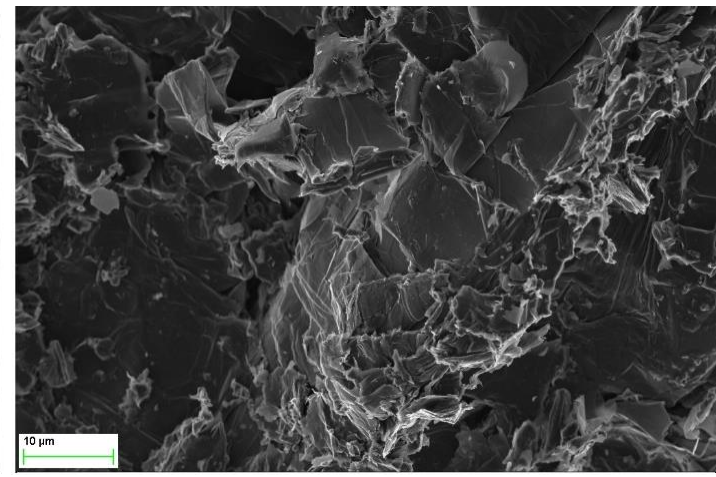

(b)

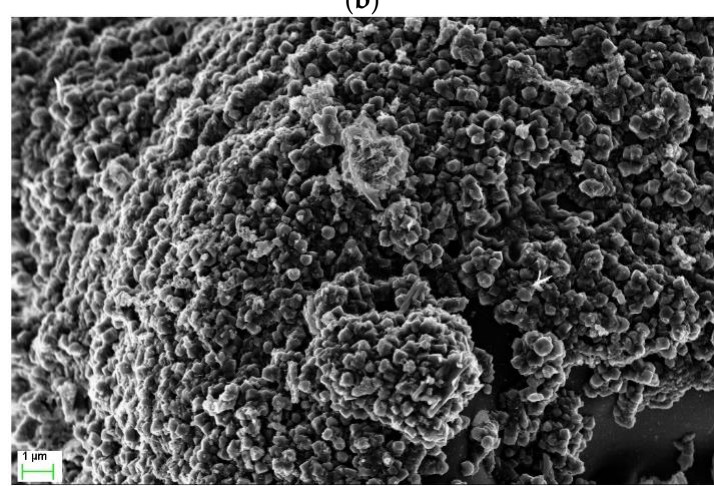

(d)

Figure 3. Representative SEM pictures of the $(\mathbf{a}, \mathbf{b})$ starting material, (c) concentrated $\mathrm{CO}_{2}$ carbonated materials at 7 bars over $4 \mathrm{~h}$ and (d) close-up of Figure 3c, showing rhombohedral calcite crystals. 
Additional insights on the progress of the carbonation reaction can be gained from TPD analysis. Figure 4 exhibits the derivative weight changes as a function of temperature in the range of $30-850{ }^{\circ} \mathrm{C}$. Untreated samples of fly ash are characterized by only one stage of mass loss, starting at $600^{\circ} \mathrm{C}$, that corresponds to precursor carbonates in the fly ash due to natural carbonation. In the treated samples, three different mass loss stages can be identified. The first one, starting at $400{ }^{\circ} \mathrm{C}$, can be attributed to portlandite decomposition, which was created during the hydration of original $\mathrm{CaO}$ [47]. The formation of portlandite could affect the final carbonation efficiency, as the $\mathrm{Ca}$ in lime is fixed by hydration in portlandite and by carbonation in calcite. At higher temperatures, carbonate decomposition can occur in the range from 600 to $650{ }^{\circ} \mathrm{C}$, leading to a much higher mass loss when compared with the untreated fly ash. The subsequent stage observed at $\mathrm{T}>650^{\circ} \mathrm{C}$ (illustrated by the positive slope of the TPD curve) indicates that further decomposition of more thermally stable carbonates continues beyond the studied temperature range, in agreement with Cwik et al., 2018 [28], due to differences in particle size and/or the presence of amorphous calcium carbonate, known to decompose at higher temperatures $[48,49]$.

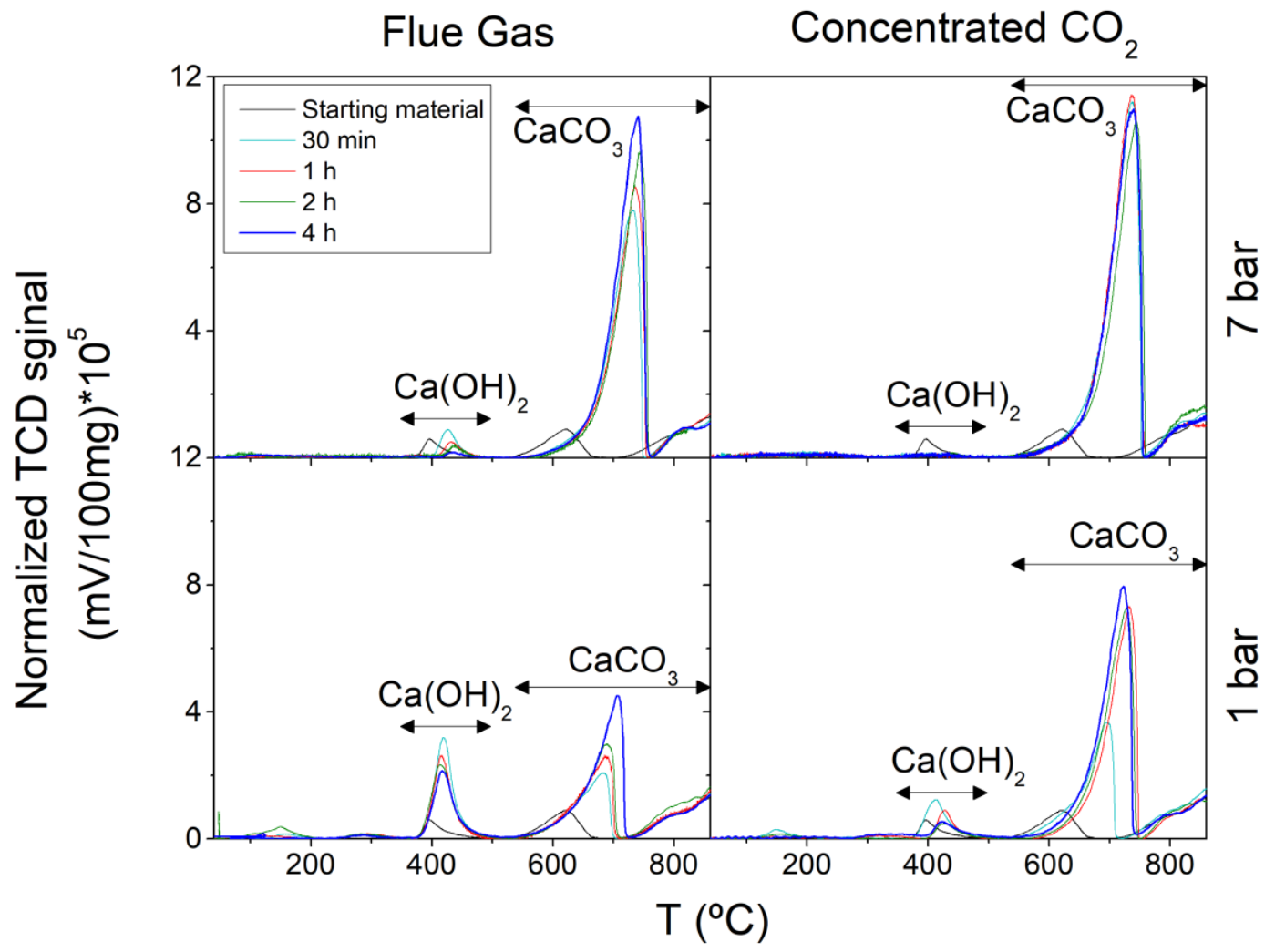

Figure 4. TPD results of the starting and carbonated materials.

\subsection{Carbonation Efficiency}

Temperature programmed desorption data were used to calculate $\mathrm{CO}_{2}$ sequestration capacity and carbonation efficiency. Based on [46,47], the following equations were used:

$$
\begin{gathered}
\mathrm{CO}_{2}^{0}(\mathrm{wt} \%)=\frac{\Delta m_{600-850^{\circ} \mathrm{C}, 0}}{m_{105^{\circ} \mathrm{C}, 0}} \times 100 \\
\Delta m^{\prime}{ }_{600-950^{\circ} \mathrm{C}}=\frac{m_{105^{\circ} \mathrm{C}}-\Delta m_{600-850^{\circ} \mathrm{C}}}{m_{105^{\circ} \mathrm{C}, 0}-\Delta m_{600-850^{\circ} \mathrm{C}, 0}} \times \Delta m_{600-850^{\circ} \mathrm{C}, 0} \\
\mathrm{CO}_{2}(\mathrm{wt} \%)=\frac{\Delta m_{600-850^{\circ} \mathrm{C}}-\Delta m^{\prime}{ }_{600-850^{\circ} \mathrm{C}}}{m_{105^{\circ} \mathrm{C}}} \times 100
\end{gathered}
$$


where $\mathrm{CO}_{2}^{0}(\mathrm{wt} \%)$ and $\mathrm{CO}_{2}(\mathrm{wt} \%)$ are the $\mathrm{CO}_{2}$ content of the starting and carbonated materials, $m_{105^{\circ} \mathrm{C}, 0}(\mathrm{~g})$ and $m_{105^{\circ} \mathrm{C}}(\mathrm{g})$ are the dry weight of the initial and carbonated sample at $105^{\circ} \mathrm{C}$, respectively, $\Delta m_{600-850^{\circ} \mathrm{C}, 0}(\mathrm{~g})$ and $\Delta m_{600-850^{\circ} \mathrm{C}}(\mathrm{g})$ are the weight loss between 600

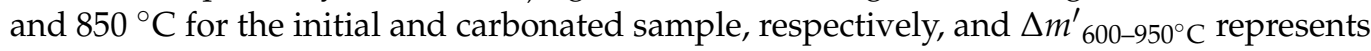
the mass loss due to $\mathrm{CO}_{2}$ release upon calcining the carbonated samples. The carbonation efficiency was calculated from the values obtained for the sequestration capacity and is expressed as a percentage of the maximum theoretical value. The results are shown in Figure 5. It should be noted that the decomposition of calcium carbonates might reach higher temperatures than those presented in this study [28]. Therefore, the calculated carbonation efficiency is likely be lower than that actually obtained.

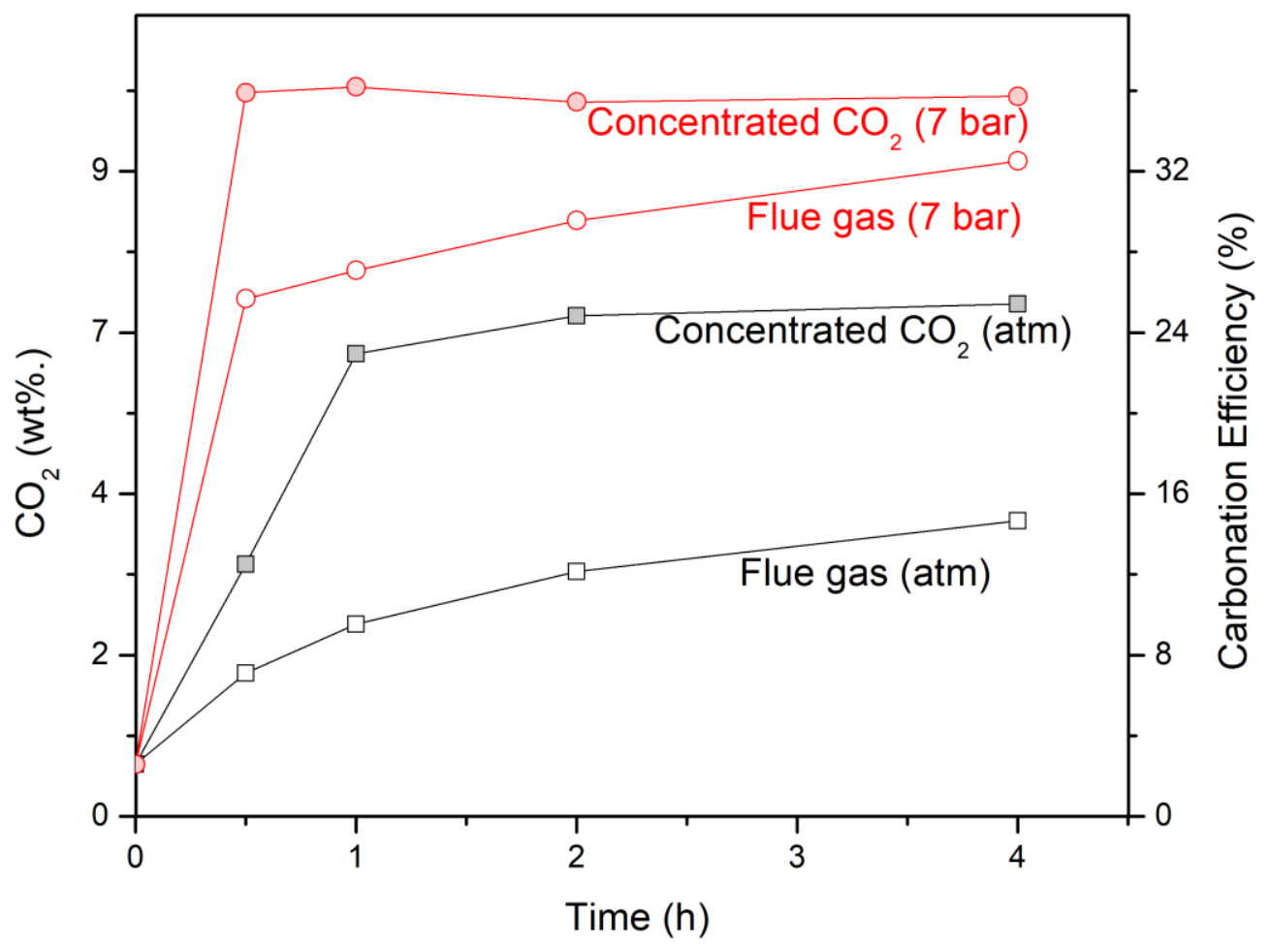

Figure 5. Carbonation efficiency (\%) and $\mathrm{CO}_{2}$ uptake (wt $\%$ ) of the samples, calculated on the basis of TPD analysis for samples treated under conditions of different pressures, times of reaction and $\mathrm{CO}_{2}$ concentrations.

The study of the evolution of the carbonation over time shed light on the reaction development. The experiments with pure $\mathrm{CO}_{2}$, maintained for $0.5 \mathrm{~h}$ at 7 bars, yielded a carbonation efficiency of $36 \%$. This value did not increase after longer reaction times, strongly suggesting that most of the carbonation is completed in the first $30 \mathrm{~min}$. Using the simulated flue gas mixture at this pressure yielded a carbonation efficiency of $28 \%$. In this case, a slight increase up to $34 \%$ was observed after $4 \mathrm{~h}$ of reaction, reaching values very similar (within $2 \%$ ) to those observed in concentrated $\mathrm{CO}_{2}$ experiments.

At atmospheric pressure, the experiment carried out with concentrated $\mathrm{CO}_{2}$ yielded an $18 \%$ carbonation efficiency after $0.5 \mathrm{~h}$, and $28 \%$ after $4 \mathrm{~h}$. On the other hand, the reaction with simulated flue gas resulted in efficiencies of $13 \%$ and $19 \%$, after $30 \mathrm{~min}$ and $4 \mathrm{~h}$, respectively. For reactions maintained at atmospheric pressure, the difference in final carbonation efficiency between concentrated $\mathrm{CO}_{2}$ and flue gas is more significant than at 7 bars. The presence of small amounts of water vapor in simulated flue gas accelerates the carbonation, as was proven in other studies [50,51]. The results from this work show that pressure is the main factor controlling the progress of the carbonation reaction, when temperature is constant, and that the rate is largely independent from the $\mathrm{CO}_{2}$ concentration of the gas, in agreement with previous investigations [52-54]. 
Other important factors impacting the final carbonation efficiency are the free lime content and presence of $\mathrm{Ca}$ in Ca-bearing compounds, described in the next section.

\subsection{Free Lime Determination}

One of the main objectives of studying the extent of carbonation of high-Ca fly ashes is to assess their valorization as a potential addition to cementitious materials. However, the free lime content is a limiting factor for such applications, since an excess of $\mathrm{CaO}$ may lead to delayed durability problems in cement-based materials. Some studies show that free lime content in fly ash, up to $4.5 \%$, might have a slight effect on the fly ash-cement mixtures [55]. This effect was due to a faster setting, higher compressive strength and higher autoclave expansion. In more recent studies, fly ashes with up to $10 \mathrm{wt} . \%$ free lime were tested as additions to cement and no effect on characteristic compressive strength was observed [56]. Other authors [27] suggest that contents of 3-6\% should not be problematic. Nevertheless, current European regulations [3] ban the use of HCFA in cement, as the maximum allowed free lime content for cement additions is $1.5 \mathrm{wt} . \%$. The strategy used in this work is lowering their free lime contents (through carbonation with either concentrated $\mathrm{CO}_{2}$ or flue gas) to values that will eventually permit the utilization of such fly ashes in the cement industry.

In this work, the amount of $\mathrm{CaO}$ in the studied samples has been determined following the procedure in Spanish UNE Standard 80-243-86. For this, $1 \mathrm{~g}$ of fly ash sample was mixed with $50 \mathrm{~mL}$ of ethylene glycol and set in a water bath at $70{ }^{\circ} \mathrm{C}$ for $30 \mathrm{~min}$. Then, the mixture was filtered under reduced pressure and the filtrate was titrated with a $10 \mathrm{~N} \mathrm{HCl}$ solution. A couple drops of Brome-cresol solution were added to the filtrate to change its color to blue. Then, the acid solution was slowly added to the filtrate until a change of color from blue to greenish yellow was observed. The total volume of $\mathrm{HCl}$ solution used was used to calculate the free lime content according to:

$$
\text { Free } \mathrm{CaO}(\%)=\frac{\mathrm{HCl}(\mathrm{mL}) \times 0.3645\left(\frac{\mathrm{g}}{\mathrm{mL}}\right)}{\text { sample weight }(\mathrm{g})}
$$

The results for samples carbonated with flue gas and concentrated $\mathrm{CO}_{2}$ at atmospheric and 7 bars pressure, over 0.5 and $4 \mathrm{~h}$, are shown in Figure 6. The starting material (untreated fly ash) is characterized by a total free lime content of $9.9 \mathrm{wt} . \%$. After carbonation with either simulated flue gas or pure $\mathrm{CO}_{2}$, all samples have experienced a significant decrease with respect to their initial free lime contents. Experiments at atmospheric pressure and $30 \mathrm{~min}$ yielded final free lime contents of 3.1 and $2.7 \mathrm{wt} . \%$ for flue gas and concentrated $\mathrm{CO}_{2}$, respectively. All the other experiments (longer reaction times at atmospheric pressure and at 7 bars), resulted in partially carbonated fly ash with final free lime contents lower than $1.0 \mathrm{wt} \%$ and, therefore, within the range established by European regulations for their utilization as additions to cement. Our results suggest that, even at atmospheric pressure, reaction times not exceeding $4 \mathrm{~h}$ should be enough to bring all treated materials to compliance with current regulations for utilization of HCFA in the cement industry.

The achieved carbonation efficiencies and free lime determination studies show that carbonation could not only be limited to free lime, but also to other Ca-bearing compounds. These compounds, however, might react at a much slower rate, owing to their slower dissolution rates when compared to free lime minerals [57].

The SEM-EDx analysis of the received fly ash shows that cenospheres contain little $\mathrm{Ca}$ (Figure A1). The observed presence of $\mathrm{Ca}$ is associated with anhydrite, which is found on the surface of this cenosphere. Therefore, cenospheres are not likely contributing to the carbonation reaction, despite their foreseen high reactivity due to their amorphous nature and the presence of carbonates on their surface upon carbonation (Figure 3a,d). Thus, the potential phases that can partially contribute to the obtained carbonation are anyhydrate and/or gehlenite. 


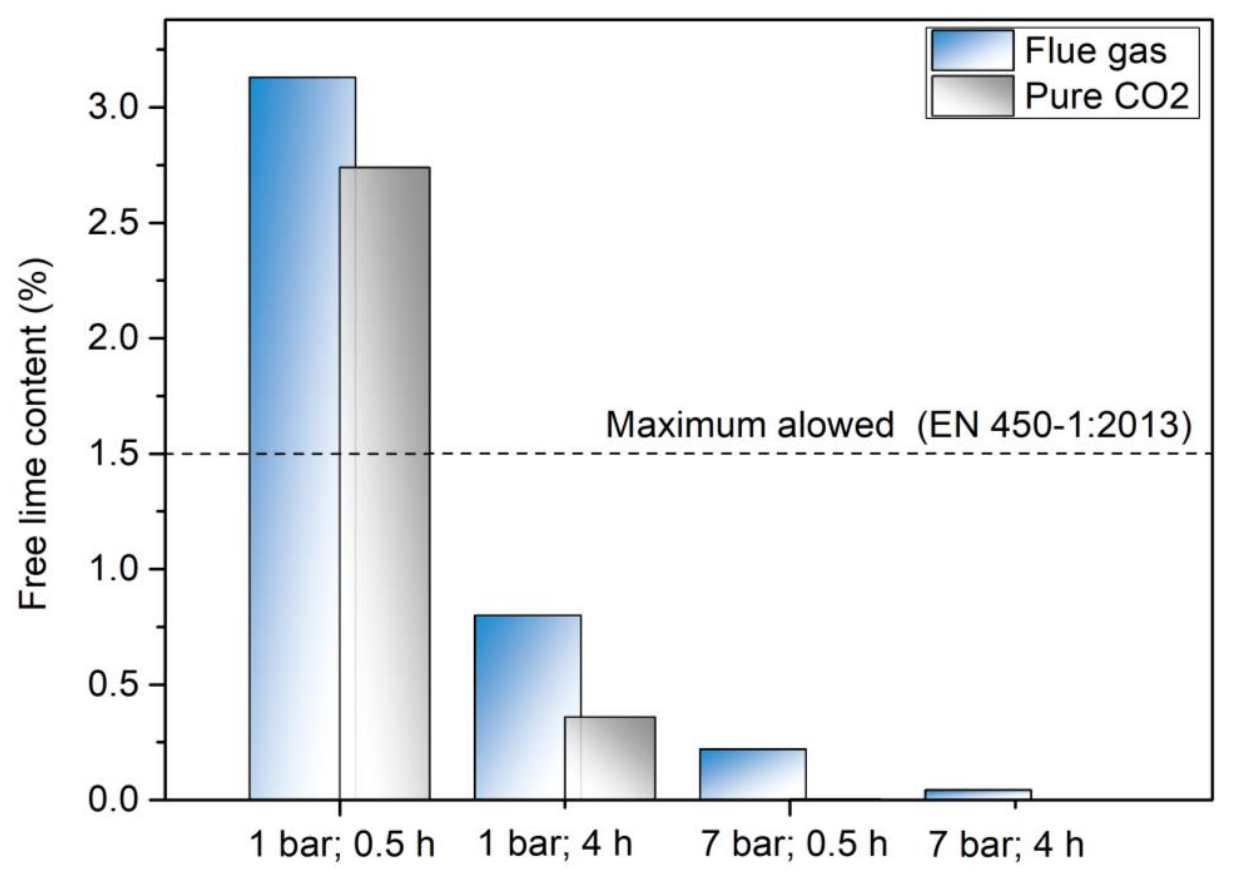

Figure 6. Free lime determination results for carbonates fly ash samples. The dashed line indicates the maximum free lime content allowed by EN 450-1:2013.

\section{Conclusions}

In this work, the carbonation of HCFA at $160{ }^{\circ} \mathrm{C}$ at atmospheric 7 bars pressure of $\mathrm{CO}_{2}$-simulated flue gas over $0.5-4 \mathrm{~h}$ was examined. The conducted analysis demonstrates that the carbonation occurred with at least $36 \%$ efficiency. The $\mathrm{CO}_{2}$ sequestration capacity of fly ash in these process conditions is $101 \mathrm{~g} \mathrm{CO}_{2} / \mathrm{kg}$ fly ash. Maintaining the reaction over different reaction times showed that at an elevated pressure, the reaction rate of carbonation is the highest during the first $0.5 \mathrm{~h}$. At atmospheric pressure, the reactions shift towards longer reaction times. It was found that carbonation by simulated flue gas leads to almost the same carbonation efficiency as concentrated $\mathrm{CO}_{2}$ at increased pressures.

The free lime evaluation test identified contents of free lime in untreated and carbonated fly ash samples. It is concluded that the carbonation process leads to a decrease in free lime content in fly ash to the values below $1.5 \%$ for both cases that used pure $\mathrm{CO}_{2}$ and flue gas.

These findings show the potential for the application of the carbonation technique at power plant sites where fly ash could be carbonated by flue gas. Using flue gas for carbonation avoids the costs of separate $\mathrm{CO}_{2}$ capture systems at power plants and preconcentration of the gas [56]. In consequence, emissions from the coal plant would be decreased and HCFA would have the optimal utilization pathway.

The simulated flue gas used in our current work contained 15\% carbon dioxide, $1 \%$ water vapor, and $84 \%$ nitrogen. An untreated coal-derived flue gas can contain: $13-16 \%$ carbon dioxide; $5-7 \%$ water vapor; $3-4 \%$ oxygen; $100-2000 \mathrm{ppm}$ sulfur dioxide; 1-40 ppm sulfur trioxide; $20-500$ ppm nitrogen oxides; $10-100$ ppm hydrogen chloride; 20 ppm carbon monoxide; 10 ppm hydrocarbons; 1 ppb total mercury; entrained fly ash particulates; and approximately $73 \%$ nitrogen $[58,59]$. The impacts of the higher levels of moisture and the acid gases, such as hydrogen chloride, sulfur oxides, and nitrogen oxides, can be examined in future research. In addition, the rate of chemical reaction to form carbonate will be impacted by temperature, particle size, and mixing. These factors can also be studied in future work. 
Author Contributions: Conceptualization, K.R. and A.Ć; methodology, K.R.; investigation, K.R. and A.Ć.; data, K.R., A.Ć.; supervision, I.C. and K.Z.; validation A.Ć.; writing-review and editing, K.R., A.Ć, I.C. and K.Z. All authors have read and agreed to the published version of the manuscript.

Funding: This work has been partially funded by the Government of Catalonia through the FI-2017 program for the recruitment of early-stage researchers. Contract number: 2017 FI_B00129 (K.R.) and by the Erasmus Mundus Joint Doctoral Programme on Environomical Pathways to Sustainable Energy Services (SELECTp; A. C.). Grant ENE2015-63969-C3-1-R (Spanish Government; IC co-I) and AGH grant number 16.16.210.476 (KZ).

Institutional Review Board Statement: Not applicable.

Informed Consent Statement: Not applicable.

Data Availability Statement: Not applicable.

Acknowledgments: This research has been carried out in the facilities of the Institute of Energy Technologies and the Barcelona Research Center for Multiscale Science and Engineering, in collaboration with UPC, Universitat Politècnica de Catalunya and AGH, University of Science and Technology. We also want to thank Nikolaus Koukouzas for distributing samples for this research. We appreciate the comments of two anonymous reviewers for their constructive comments.

Conflicts of Interest: The authors declare no conflict of interest.

\section{Appendix A}
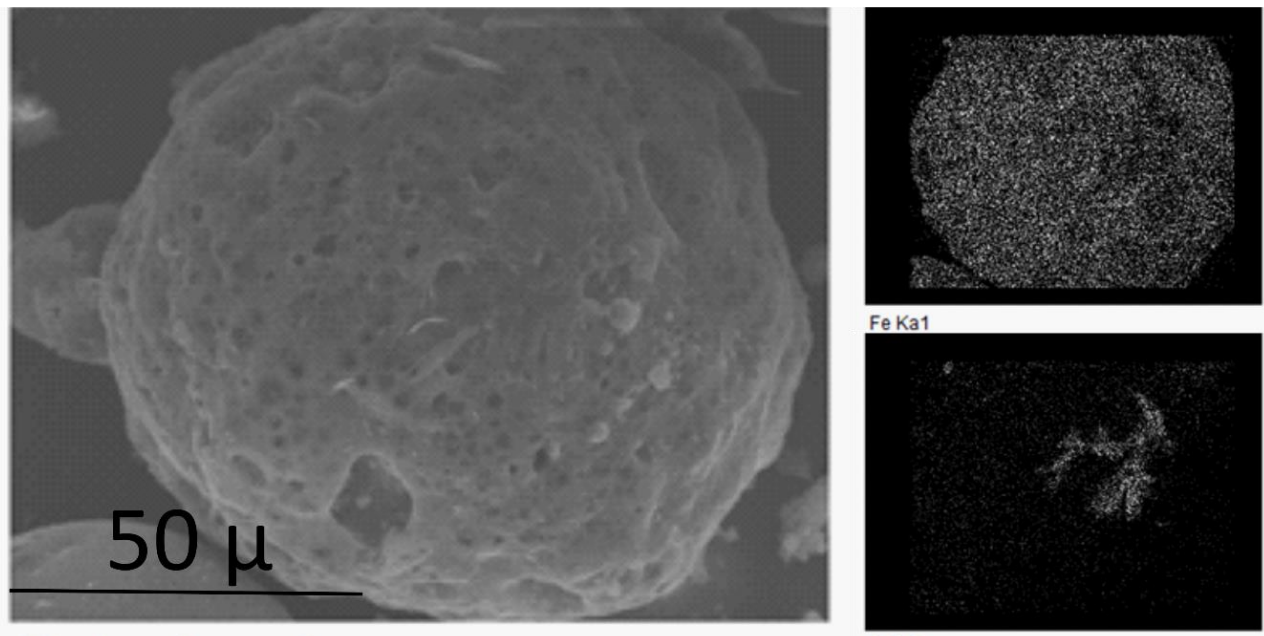

Electron Image 1
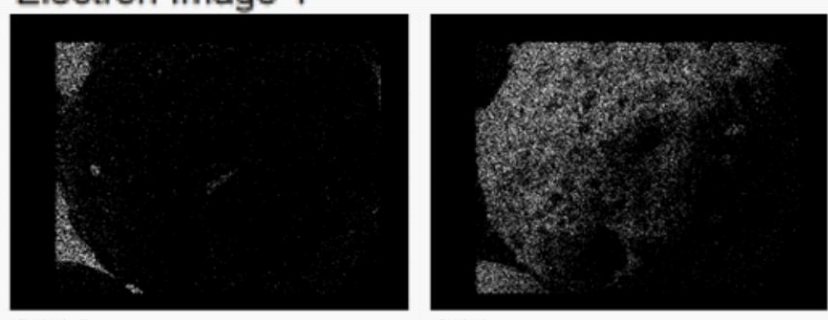

SKa1
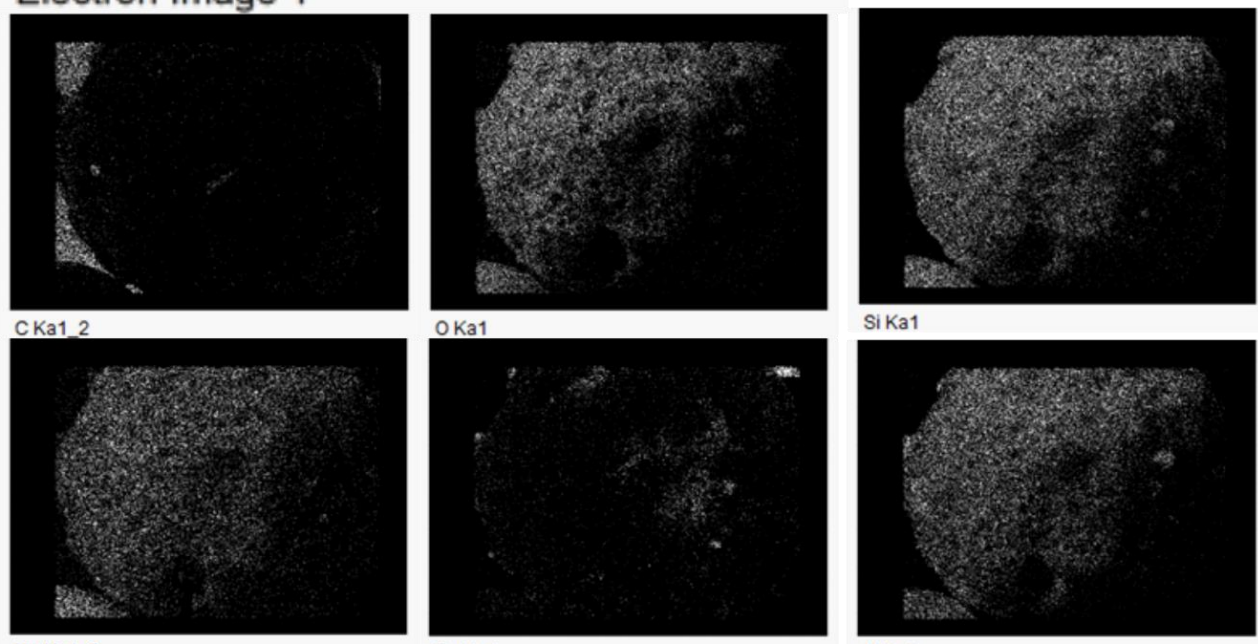

Si Ka1

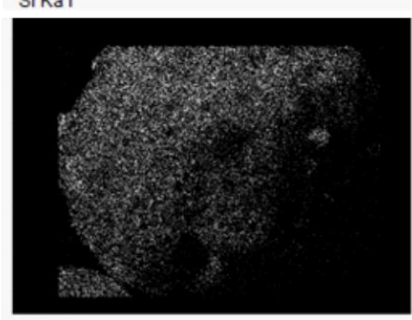

Mg Ka1_2

Ca Ka1

Al Ka1

Figure A1. SEM-EDx analysis of a cenosphere from received fly ash. This cenosphere is mainly composed of $\mathrm{Al}, \mathrm{Fe}, \mathrm{Si}$ and $\mathrm{Mg}$. The presence of anhydrite is also observed on this cenospheres as evidenced by the concurring presence of Ca and $\mathrm{S}$, taking into account the composition and possible phases identified with XRD (Figure 1). 


\section{References}

1. ASTM C618-05, Standard Specification for Coal Fly Ash and Raw or Calcined Natural Pozzolan for Use in Concrete; ASTM International: West Conshohocken, PA, USA, 2005.

2. Papayianni, I.; Tsimas, S.; Moutsatsou, A. Standardization aspects concerning high calcium fly ashes. In Proceedings of the 2009 World of Coal Ash (WOCA) Conference, Lexington, KY, USA, 4-7 May 2009.

3. Fly Ash for Concrete-Part 1: Definition, Specifications and Conformity Criteria 2012; EN 450-1:2013 UNE-EN 450-1:2013. Available online: https:/ /infostore.saiglobal.com/preview /98701122690.pdf?sku=871436_SAIG_NSAI_NSAI_20720611461445 (accessed on 27 October 2021).

4. Heidrich, C.; Feuerborn, H.; Weir, A. Coal Combustion Products: A Global Perspective. In Proceedings of the 2013 World of Coal Ash (WOCA) Conference, Lexington, KY, USA, 22-25 April 2013.

5. Feuerborn, H. Calcareous Ash in Europe-A reflection on technical and legal issues. In Proceedings of the 2nd Hellenic Conference on Utilisation of Industrial By-Products in Construction, Aiani Kozani, Greece, 1-3 June 2009.

6. Ahmaruzzaman, M. A review on the utilization of fly ash. Prog. Energy Combust. Sci. 2010, 36, 327-363. [CrossRef]

7. Part 1: Composition, Specifications and Conformity Criteria for Common Cement; EN 197-1:2011 Cement; 2011. Available online: https:// www.en-standard.eu/bs-en-197-1-2011-cement-composition-specifications-and-conformity-criteria-for-common-cements / (accessed on 27 October 2021).

8. Feuerborn, H.J.; Müller, B.; Walter, E. Use of Calcareous Fly Ash in Germany. Ash Handl. 2012, 3, 17-29.

9. Uliasz-Bochenczyk, A. Waste used for $\mathrm{CO}_{2}$ bonding via mineral carbonation. Gospod. Surowcami Miner. 2007, 23, 121-128.

10. Argiz, C.; Menéndez, E.; Moragues, A.; Sanjuán, M.A. A Fly ash characteristics of Spanish coal-fired power plants. Afinidad 2015, 72, 269-277.

11. International Energy Agency. Market Report Series Gas 2018; International Energy Agency: Paris, France, 2018.

12. Papayianni, J. Use of a high-calcium fly ash in blended type cement production. Cem. Concr. Compos. 1993, 15, 231-235. [CrossRef]

13. Dong, Y.; Jow, J.; Su, J.; Lai, S. Fly Ash Separation Technology and Its Potential Applications. Available online: http://www. mcilvainecompany.com/Decision_Tree/subscriber/Tree/DescriptionTextLinks/Chinese\%20flyash\%20separation.pdf (accessed on 27 October 2021).

14. Naik, T.R.; Singh, S.S. Use of High-Calcium Fly Ash in Cement-Based Construction Materials. In Proceedings of the Fifth CANMET/ACI International Conference on Fly Ash, Silica Fume, Slag and Natural Pozzolans in Concrete; 1994. Available online: https:/ / www.concrete.org/store/productdetail.aspx?ItemID=SP153\&Format=DOWNLOAD\&Language=English\& Units=US_Units (accessed on 27 October 2021).

15. Matter, J.M.; Kelemen, P. Permanent storage of carbon dioxide in geological reservoirs by mineral carbonation. Nat. Geosci. 2009, 2, 837-841. [CrossRef]

16. Lackner, K.S.; Wendt, C.H.; Butt, D.P.; Joyce, E.L.; Sharp, D.H. Carbon dioxide disposal in carbonate minerals. Energy 1995, 20, 1153-1170. [CrossRef]

17. Li, J.; Hitch, M. Mechanical activation of magnesium silicates for mineral carbonation, a review. Miner. Eng. 2018, 128, 69-83. [CrossRef]

18. Bobicki, E.R.; Liu, Q.; Xu, Z.; Zeng, H. Carbon capture and storage using alkaline industrial wastes. Prog. Energy Combust. Sci. 2012, 38, 302-320. [CrossRef]

19. Rahmani, O. $\mathrm{CO}_{2}$ sequestration by indirect mineral carbonation of industrial waste red gypsum. J. $\mathrm{CO}_{2}$ Util. 2018, 27, 374-380. [CrossRef]

20. Benhelal, E.; Rashid, M.; Holt, C.; Rayson, M.; Brent, G.; Hook, J.; Stockenhuber, M.; Kennedy, E. The utilisation of feed and byproducts of mineral carbonation processes as pozzolanic cement replacements. J. Clean. Prod. 2018, 186, 499-513. [CrossRef]

21. Fernandezbertos, M.; Simons, S.; Hills, C.; Carey, P. A review of accelerated carbonation technology in the treatment of cementbased materials and sequestration of $\mathrm{CO}_{2}$. J. Hazard. Mater. 2004, 112, 193-205. [CrossRef] [PubMed]

22. Reynolds, B.; Reddy, K.J.; Argyle, M.D. Field Application of Accelerated Mineral Carbonation. Minerals 2014, 4, 191-207. [CrossRef]

23. Ebrahimi, A.; Saffari, M.; Milani, D.; Montoya, A.; Valix, M.; Abbas, A. Sustainable transformation of fly ash industrial waste into a construction cement blend via $\mathrm{CO}_{2}$ carbonation. J. Clean. Prod. 2017, 156, 660-669. [CrossRef]

24. Pei, S.-L.; Pan, S.-Y.; Gao, X.; Fang, Y.-K.; Chiang, P.-C. Efficacy of carbonated petroleum coke fly ash as supplementary cementitious materials in cement mortars. J. Clean. Prod. 2018, 180, 689-697. [CrossRef]

25. Ji, L.; Yu, H.; Wang, X.; Grigore, M.; French, D.; Gözükara, Y.M.; Yu, J.; Zeng, M. $\mathrm{CO}_{2}$ sequestration by direct mineralisation using fly ash from Chinese Shenfu coal. Fuel Process. Technol. 2017, 156, 429-437. [CrossRef]

26. Nyambura, M.G.; Mugera, G.W.; Felicia, P.L.; Gathura, N.P. Carbonation of brine impacted fractionated coal fly ash: Implications for CO2 sequestration. J. Environ. Manag. 2011, 92, 655-664. [CrossRef] [PubMed]

27. Wei, Z.; Wang, B.; Falzone, G.; La Plante, E.C.; Okoronkwo, M.U.; She, Z.; Oey, T.; Balonis, M.; Neithalath, N.; Pilon, L.; et al. Clinkering-free cementation by fly ash carbonation. J. $\mathrm{CO}_{2}$ Util. 2018, 23, 117-127. [CrossRef]

28. Ćwik, A.; Casanova, I.; Rausis, K.; Koukouzas, N.; Zarębska, K. Carbonation of high-calcium fly ashes and its potential for carbon dioxide removal in coal fired power plants. J. Clean. Prod. 2018, 202, 1026-1034. [CrossRef] 
29. Ćwik, A.; Casanova, I.; Rausis, K.; Zarębska, K. Utilization of high-calcium fly ashes through mineral carbonation: The cases for Greece, Poland and Spain. J. $\mathrm{CO}_{2}$ Util. 2019, 32, 155-162. [CrossRef]

30. Aouini, I.; LeDoux, A.; Estel, L.; Mary, S. Pilot Plant Studies for $\mathrm{CO}_{2}$ Capture from Waste Incinerator Flue Gas Using MEA Based Solvent. Oil Gas Sci. Technol. Rev. IFP 2014, 69, 1091-1104. [CrossRef]

31. Jecht, U. Flue Gas Analysis in Industry —Practical guide for Emission and Process Measurements; Testo: Titisee-Neustadt, Germany, 2004; pp. 1-145.

32. Rausis, K.; Ćwik, A.; Casanova, I. Phase evolution during accelerated $\mathrm{CO}_{2}$ mineralization of brucite under concentrated $\mathrm{CO}_{2}$ and simulated flue gas conditions. J. $\mathrm{CO}_{2}$ Util. 2019, 37, 122-133. [CrossRef]

33. Revathy, T.D.R.; Ramachandran, A.; Palanivelu, K. Carbon capture and storage using coal fly ash with flue gas. Clean Technol. Environ. Policy 2021, 1-19. [CrossRef]

34. Myers, C.A.; Nakagaki, T.; Akutsu, K. Quantification of the $\mathrm{CO}_{2}$ mineralization potential of ironmaking and steelmaking slags under direct gas-solid reactions in flue gas. Int. J. Greenh. Gas Control 2019, 87, 100-111. [CrossRef]

35. Mouedhen, I.; Kemache, N.; Pasquier, L.-C.; Cecchi, E.; Blais, J.-F.; Mercier, G. Effect of $\mathrm{pCO}_{2}$ on direct flue gas mineral carbonation at pilot scale. J. Environ. Manag. 2017, 198, 1-8. [CrossRef]

36. Zhang, Y.; Xie, Y.; Zhu, Y.; Lu, X.; Ji, X. Energy Consumption Analysis for $\mathrm{CO}_{2}$ Separation from Gas Mixtures with Liquid Absorbents. Energy Procedia 2014, 61, 2695-2698. [CrossRef]

37. White, C.M.; Strazisar, B.R.; Granite, E.J.; Hoffman, J.S.; Pennline, H.W. Separation and Capture of $\mathrm{CO}_{2}$ from Large Stationary Sources and Sequestration in Geological Formations-Coalbeds and Deep Saline Aquifers. J. Air Waste Manag. Assoc. 2003, 53, 645-715. [CrossRef]

38. Galan, I.; Glasser, F.; Baza, D.; Andrade, C. Assessment of the protective effect of carbonation on portlandite crystals. Cem. Concr. Res. 2015, 74, 68-77. [CrossRef]

39. Kontoyannis, C.G.; Vagenas, N.V. Calcium carbonate phase analysis using XRD and FT-Raman spectroscopy. Analyst 2000, 125, 251-255. [CrossRef]

40. Mozgawa, W.; Król, M.; Dyczek, J.; Deja, J. Investigation of the coal fly ashes using IR spectroscopy. Spectrochim. Acta Part A Mol. Biomol. Spectrosc. 2014, 132, 889-894. [CrossRef] [PubMed]

41. Khouzani, M.F.; Chevrier, D.M.; Güttlein, P.; Hauser, K.; Zhang, P.; Hedin, N.; Gebauer, D. Disordered amorphous calcium carbonate from direct precipitation. CrystEngComm 2015, 17, 4842-4849. [CrossRef]

42. Vassilev, S.V.; Menendez, R.; Alvarez, D.; Diaz-Somoano, M.; Martinez-Tarazona, M.R. Phase-mineral and chemical composition of coal fly ashes as a basis for their multicomponent utilization. 1. Characterization of feed coals and fly ashes. Fuel 2003, 82, 1793-1811. [CrossRef]

43. Żyrkowski, M.; Neto, R.C.; Santos, L.F.; Witkowski, K. Characterization of fly-ash cenospheres from coal-fired power plant unit. Fuel 2016, 174, 49-53. [CrossRef]

44. Rochelle, C.A.; Czernichowski-Lauriol, I.; Milodowski, A. The impact of chemical reactions on $\mathrm{CO}_{2}$ storage in geological formations: A brief review. Geol. Soc. Lond. Spec. Publ. 2004, 233, 87-106. [CrossRef]

45. Kremer, B.; Kaźmierczak, J.; Stal, L.J. Calcium carbonate precipitation in cyanobacterial mats from sandy tidal flats of the North Sea. Geobiology 2007, 6, 46-56. [CrossRef] [PubMed]

46. Regnault, O.; Lagneau, V.; Schneider, H. Experimental measurement of portlandite carbonation kinetics with supercritical $\mathrm{CO}_{2}$. Chem. Geol. 2009, 265, 113-121. [CrossRef]

47. Rodriguez, E.T.; Garbev, K.; Merz, D.; Black, L.; Richardson, I. Thermal stability of C-S-H phases and applicability of Richardson and Groves' and Richardson C-(A)-S-H(I) models to synthetic C-S-H. Cem. Concr. Res. 2017, 93, 45-56. [CrossRef]

48. Escardino, A.; García-Ten, J.; Feliu, C.; Saburit, A.; Cantavella, V. Kinetic study of the thermal decomposition process of calcite particles in air and $\mathrm{CO}_{2}$ atmosphere. J. Ind. Eng. Chem. 2012, 19, 886-897. [CrossRef]

49. Montes-Hernandez, G.; Daval, D.; Chiriac, R.; Renard, F. Growth of Nanosized Calcite through Gas-Solid Carbonation of Nanosized Portlandite under Anisobaric Conditions. Cryst. Growth Des. 2010, 10, 4823-4830. [CrossRef]

50. Manovic, V.; Anthony, E.J. Carbonation of CaO-based sorbents enhanced by steam addition. Ind. Eng. Chem. Res. 2010, 49, 9105-9110. [CrossRef]

51. Liu, W.; Su, S.; Xu, K.; Chen, Q.; Xu, J.; Sun, Z.; Wang, Y.; Hu, S.; Wang, X.; Xue, Y.; et al. $\mathrm{CO}_{2}$ sequestration by direct gas-solid carbonation of fly ash with steam addition. J. Clean. Prod. 2018, 178, 98-107. [CrossRef]

52. Tosun, Y.I. Benefaction from Carbonation of Flue Gas $\mathrm{CO}_{2}$ as Coal Mining Filling. Geomaterials 2014, 4, 64-72. [CrossRef]

53. Veetil, S.P.; Mercier, G.; Blais, J.F.; Cecchi, E.; Kentish, S. $\mathrm{CO}_{2}$ Sequestration by Direct Dry Gas-Solid Contact of Serpentinite Mining Residues: A Solution for Industrial $\mathrm{CO}_{2}$ Emission. Int. J. Environ. Pollut. Remediat. 2014, 2, 52-58. [CrossRef]

54. Werner, M.; Hariharan, S.; Bortolan, A.V.; Zingaretti, D.; Baciocchi, R.; Mazzotti, M. Carbonation of Activated Serpentine for Direct Flue Gas Mineralization. Energy Procedia 2013, 37, 5929-5937. [CrossRef]

55. Kaewmanee, K.; Krammart, P.; Sumranwanich, T.; Choktaweekarn, P.; Tangtermsirikul, S. Effect of free lime content on properties of cement-fly ash mixtures. Constr. Build. Mater. 2013, 38, 829-836. [CrossRef]

56. Nawaz, A.; Julnipitawong, P.; Krammart, P.; Tangtermsirikul, S. Effect and limitation of free lime content in cement-fly ash mixtures. Constr. Build. Mater. 2016, 102, 515-530. [CrossRef]

57. Sanna, A.; Uibu, M.; Caramanna, G.; Kuusik, R.; Maroto-Valer, M. A review of mineral carbonation technologies to sequester $\mathrm{CO}_{2}$. Chem. Soc. Rev. 2014, 43, 8049-8080. [CrossRef] 
58. Granite, E.J.; Pennline, H.W.; Connie, S. Mercury Control: For Coal-Derived Gas Streams; John Wiley \& Sons: New York, NY, USA, 2015.

59. Senior, C.; Granite, E.; Linak, W.; Seames, W. Chemistry of Trace Inorganic Elements in Coal Combustion Systems: A Century of Discovery. Energy Fuels 2020, 34, 15141-15168. [CrossRef] 